\title{
The Effect of SEZ Investment and Development on Labor Absorption
}

\author{
Bambang Jatmiko ${ }^{1, *}$, Titi Laras ${ }^{2}$, Udin Udin ${ }^{3}$, Siti Dyah Handayani ${ }^{4}$, Rini Raharti ${ }^{5}$, Alfi \\ Muthia Anjani ${ }^{6}$
}

\author{
${ }^{1}$ Department of Accounting, Faculty of Economics and Business, Universitas Muhammadiyah Yogyakarta, Indonesia \\ ${ }^{2}$ Department of Management, Faculty of Economics, Universitas Janabadra, Indonesia \\ ${ }^{3,4}$ Department of Management, Faculty of Economics and Business, Universitas Muhammadiyah Yogyakarta, Indonesia \\ ${ }^{5}$ Department of Economics, Faculty of Economics, Universitas Janabadra, Indonesia \\ ${ }^{6}$ Department of Agrotechnology, Faculty of Agriculture, Universitas Muhammadiyah Yogyakarta, Indonesia \\ ${ }^{*}$ Corresponding author. Email: bambang.jatmiko@umy.ac.id
}

\begin{abstract}
The objectives of this study are to test and prove 1) the effect of investment in Special Economic Zones (SEZ) on labor absorption, 2) the effect of the development of Special Economic Zones on labor absorption empirically, and 3) the effect of investment and development of Special Economic Zones on labor absorption. The problem in this research is that the world investment in Indonesia still reaches $1.97 \%$. The average foreign investment to Indonesia in 2012-2016 was US \$ 1,417.58 billion per year. In addition, the achievement of the investment ratio target has also only reached $32.7 \%$ or was below the National Medium Term Development Plan (RPJMN) target of 38.9\% in 2019. This research method used a survey with secondary data (web, documents, and data from the Central Bureau of Statistics). The sampling technique employed non-probability sampling with saturated sampling. Saturated sampling is a sampling technique when all members of the population are used as samples. In this study, the sampling used 15 areas with 43 business units. The analysis results showed that 1) investment did not have a significant effect on labor absorption; 2) development did not have a significant effect on labor absorption; 3) investment and development simultaneously or together did not have a significant effect on labor absorption variables.
\end{abstract}

Keywords: Investment, Development, Labor Absorption, Special Economic Zones

\section{INTRODUCTION}

Law No. 39 of 2009 Article 38 explains that in the Special Economic Zones (SEZ), facilities and reliefs are given in the fields of business licensing, business activities, industry, trade, ports, and immigration for foreign business actors, as well as secure facilities, which is updated by Government Regulation of the Republic of Indonesia No. 12 of 2020 concerning facilities and conveniences in the Special Economic Zones. The facilities provided to SEZ are aimed at increasing competitiveness so that it is more attractive to investors. In principle, SEZ has implemented an Online Single Submission (OSS) system to make it easier for business actors to obtain a Business Identification Number (BIN), which the SEZ administrator can assist in its implementation.

In the field of customs, facilities and reliefs include a) business entities that are granted import duty (BM) exemption in the framework of development and b) postponement of import duty (BM) for business actors (not applicable in the Tourism SEZ). In the excise sector, the facilities and conveniences provided are exempt from excise duty for raw materials or auxiliary materials in the manufacture of final products that are not excisable goods. On immigration, facilities provided by the government include a) a visit visa on arrival for 30 days and can be extended five times for 30 days each, b) multiple entry visas for foreigners and their families, c) special visas or residence permits for foreigners who own property in the SEZ Tourism, and d) special visas or residence permits for elderly foreigners living in the SEZ Tourism. In terms of employment, facilities include a) the establishment of Special Tripartite Wage Council and Cooperation Institutions (LKS) in SEZ, b) the existence of only one Trade Union (SP)/Labor Union (SB) forum in each company, c) the ratification and extension of the Plan for the Use of Foreign Workers (RPTKA) in SEZ, and d) the extension of Permit to Use Foreign Workers (IMTA) in the SEZ.

Based on the above policy, the researchers also refer to the previous research results conducted by Warr and Jayanti that in SEZs, the legal, logistical, and tax arrangements are intended to assist a developing country in attracting exportoriented manufacturing investment (mainly foreign), not otherwise [1]. Additionally, these zones share features that 
contribute to the "special" nature of the SEZ. These are: (1) an extraordinary administrative system: zones regularly work under more liberal monetary laws than those that ordinarily win, seeing issues like work, land use, and unfamiliar speculation. (2) Regarding public administrations, zones are typically overhauled with effective traditions, quick track enlistment, and permitting, frequently through "all in one resource" administrations. (3) The next feature is the framework, in which zones have a much better and more dependable foundation like streets, force, and water, contrasted with the homegrown financial climate. Also, (4) concerning financial motivators, the zone's financial backers, especially its anchor financial backers, frequently appreciate capital opportunities and certain degrees of expense impetuses and sponsorships [2]. In addition, unique monetary zones (SEZs) have added to financial improvement in a few nations while being completely fruitless in others. Numerous SEZs also offer a changing business environment and lower duties and levies [3]. It empowers ventures and makes a thriving business local area.

The results of the provisional mapping of investment, development, and employment of Special Economic Zones (SEZ) in Indonesia can be seen as follows:

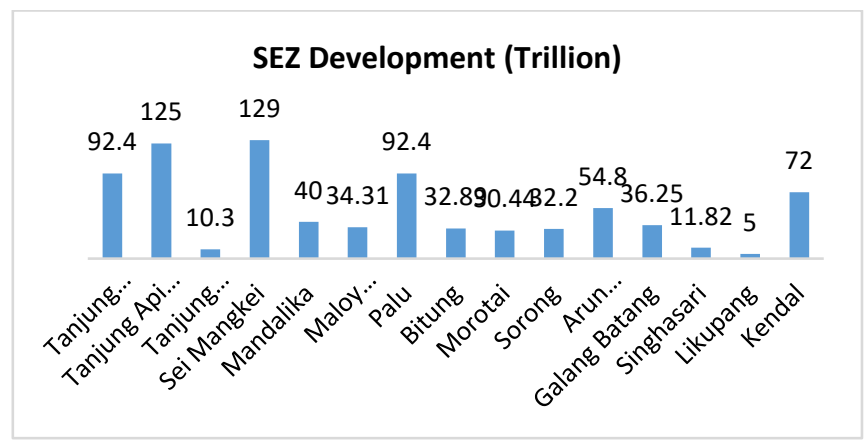

Figure 1. SEZs Investment

Source: KEK National Council, reprocessed by researchers

Figure 1. explains that the results of the mapping of investments in all Special Economic Zones in Indonesia can be seen in the investment rankings as follows: 1) Sei Mangkei (rank 1);2) Tanjung Api-Api (rank 2); 3) Tanjung Lesung and Palu (rank 3); 4) Kendal (rank 4); 5) Arun Lhokseumawe (rank 5); 6) Mandalika (rank 6); 7) Galang Batang (rank 7); 8) Maloy Batuta Trans Kalimantan (rank 8); 9) Bitung (rank 9); 10) Sorong (rank 10); 11) Morotai (rank 11); 12) Singhasari (rank 12); 13) Tanjung Kelayang (rank 13); 14) Likupang (rank 14).

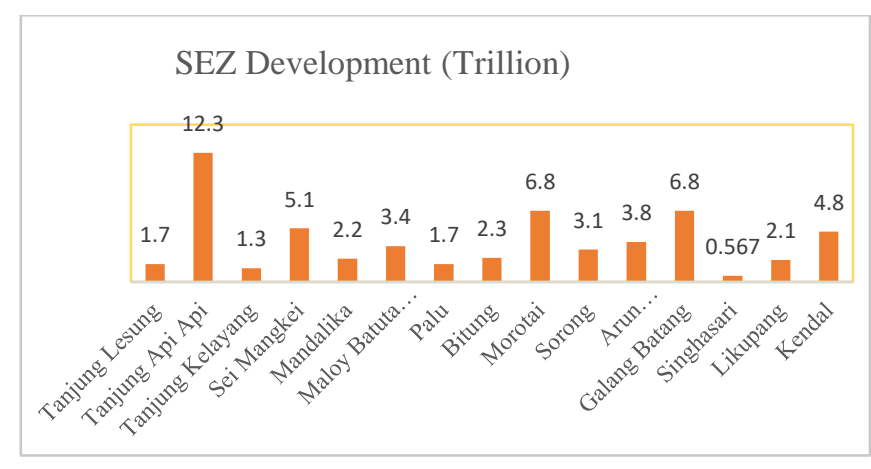

Figure 2. SEZs Development

Source: KEK National Council, reprocessed by researchers

Figure 2. displays that the results of the development mapping implanted in all Special Economic Zones in Indonesia can be seen in the development rankings as follows: 1) Tanjung Api Api (rank 1); 2) Morotai and Galang Batang (rank 2); 3) Sei Mangkei (rank 3); 4) Kendal (rank 4); 5) Arun Lhokseumawe (rank 5); 6) Maloy Batuta Trans Kalimantan (rank 6); 7) Sorong (rank 7); 8) Bitung (rank 8); Mandalika (rank 9); 10) Likupang (rank 10); 11) Tanjung Lesung and Palu (rank 11); 12) Tanjung Kelayang (rank 12); 13) Singhasari (rank 13).

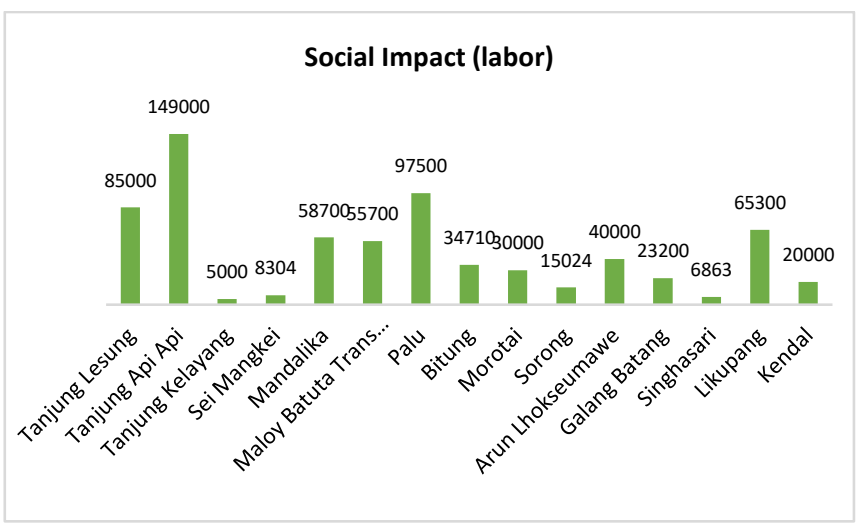

Figure 3. Workforce Social Impact

Source: KEK National Council, reprocessed by researchers

Figure 3. describes that the results of the mapping of the workforce absorbed in all Special Economic Zones in Indonesia can be seen in the rankings as follows: 1) Tanjung Api-Api (rank 1); 2) Hammer (rank 2); 3) Tanjung Lesung (rank 3); 4) Likupang (rank 4); 5) Mandalika (rank 5); 6) Maloy Trans Batuta Kalimantan (rank 6); 7) Arun Lhokseumawe (rank 7); 8) Bitung 9 (rank 8); 9) Morotai (rank 9); 10) Galang Batang (rank 10); 11) Kendal (rank 11); 12) Sorong (rank 12); 13) Sei Mangkei (rank 13); 14) Siunghasari (rank 14); 15) Tanjung Kelayang (rank 15).

As for the national investment problem, according to the Coordinating Minister for Economic Affairs, Darmin Nasution, the growth of investment realization is still below the target set [4]. According to Darmin, it can be seen, among 
others, from the share of world investment in Indonesia, which still reaches $1.97 \%$. The mean foreign investment to Indonesia in 2012-2016 was the US \$ 1,417.58 billion per year. In addition, the achievement of the investment ratio target has also only reached $32.7 \%$ or was below the National Medium-Term Development Plan (RPJMN) target of $38.9 \%$ in 2019. Moreover, investment realization is still low than submitting investment commitments for foreign investment (PMA) by $27.5 \%$ and domestic investment (PMDN) by $31.8 \%$. The investment invested by investors is also not yet balanced, where investment in Java is still above $50 \%$ or higher than investment outside Java.

Therefore, the targets of this investigation are as follows: 1) to test and prove SEZ investment on labor absorption empirically, 2) to test and prove the development of SEZ on labor absorption empirically, and 3) jointly to test and prove SEZ investment and development on labor absorption empirically.

\section{LITERATURE REVIEW}

\subsection{Investment}

Investment is defined as the responsibility of current monetary assets to accomplish higher increases later. It manages what are called vulnerability areas [5]. From this definition, the significance of time and future emerges as they are two significant components in the venture. Investment is also the penance of assets (time, cash, and exertion) today for the assumption for procuring more assets tomorrow [6]. From a limited perspective, the investment environment alludes to the different speculation resources (or instruments) that people and foundations can purchase and sell, just as the business sectors in which these resources are exchanged. The assets can be assembled into two significant classifications: real and financial assets [5][6]. Real assets are substantial resources used to deliver merchandise or administrations, like structures, land, hardware, or intellectual resources to create items or administrations. Meanwhile, financial assets are claims to genuine resources or payments delivered by those resources. The models incorporate stocks and securities distant from everyone else, close to useless papers, and do not straightforwardly add to the creation of ware or administration; however, they get their worth from the cases they convey. In indirect investing, it involves financial intermediaries.

There are two types of investors: individual investors and institutional investors [7]. Individual investors are contributing all alone. Sometimes, individual investors are called retail investors. On the other side, institutional investors are elements, for example, speculation organizations, business banks, insurance agencies, benefits reserves, and other monetary establishments. Lately, the cycle of standardization of investors can be observed. As the fundamental explanations behind, this can be referenced the reality that institutional financial backers can accomplish economies of scale, segment tension on federal retirement aid, the changing part of banks. Investors can also use a direct or indirect type of investing. Direct investment is "a class of cross-line speculation concerned with an inhabitant in one economy, having control or a huge level of effect on the administration of an undertaking, who is an occupant in another economy" [8].

Moreover, a generic term for a financial asset is security [6]. Security is a legal claim on the revenue streams of financial assets or real assets. Examples of securities with claims on a financial asset are bonds and stocks. Although many securities have specific collateral (or pledges) to back up the claim to a revenue stream, others have not but simply represented a promise to pay.

Financial securities are classified into three major categories: equity, debt, and derivative securities. In addition, value protections, or basic stocks, address a possession interest in an organization. A typical investor is a financial backer who possesses an offer in an organization, and each offer qualifies the proprietor for one vote in the enterprise's significant monetary issue. Meanwhile, debt securities are claims on some known, periodic stream of payments until the end of their life (the maturity date). Debt securities are also known as fixed-income securities because they promise a fixed stream of payments based on some formula. Then, the most important category of debt securities is a bond. A bond is a contractual obligation of the issuer (or seller) of the bond to repay the holder (or buyer) of the bond a certain amount of interest on the loan on fixed dates throughout its life plus the loan's principal (or initial amount lent) at the maturity date.

Moreover, derivative securities, also known as contingent claims, are securities whose values are derived from (or are contingent upon) the underlying asset(s). The two most important types of such securities are options and futures. In general, an option entitles (or gives the right, but not the obligation to) its owner to buy (a call option) or sell (a put option) something on or before some specific point in time.

\subsection{Development}

Development has often been confused with "economic growth as measured solely in terms of annual increases in percapita income or gross national product, regardless of its distribution and the degree of people's participation in effective growth" [9]. In fact, development means the conditions for the realization of the human personality. Its evaluation must therefore take into account three linked criteria: where there has been a reduction in (1) poverty, (2) unemployment, and (3) inequality [10]. Through this cycle, the general public guarantees the development in abundance, security and mental enhancement, and the advancement of the quality of the everyday environments of many individuals. Society utilizes a blend of social, monetary, and institutional cycles to obtain better everyday environments. This definition of development generates the following development objectives: 
a) To increment the accessibility and dissemination of the essential products required for human existence - food. Such essential products incorporate food, sanctuary, wellbeing, and security.

b) To improve the degree of living regarding social perspectives like family and public salaries, instruction, and human social qualities, for the upgrade of individual and public material prosperity and confidence

c) To extend the scope of the accessible individual and public financial and social decisions by liberating them from bondage by powers of obliviousness and human wretchedness from one viewpoint and reliance from other people and countries on the other

In addition, development is a cycle of expanding an individual's decision, which incorporates, among others, openings for being imaginative and useful just as to gain selfcompletion and confidence [11]. Development is also "both a physical reality and a state of mind in which society has secured the means for obtaining a better life" [12].

\subsection{Employment}

Labor absorption is the number of occupations that have been filled, which is reflected in the number of working individuals. The working population is absorbed and spread across various sectors of the economy [13]. The absorption of the working population is of the interest in work. Labor is an essential factor in other production processes, such as land, capital, and others. Thus, humans are the driving force for all these production factors. Besides, labor is needed by companies or institutions with certain levels of wages, positions, and working conditions. However, data on real employment opportunities are difficult to obtain, so for practical purposes, an approach is used, where the number of job opportunities is approached through the number of job opportunities filled as reflected in the number of working people or, more accurately called labor absorption.

\subsection{Special Economic Zones}

Based on Law No. 39 of 2009, Special Economic Zones (SEZ) are areas with certain boundaries within the jurisdiction of the Unitary State of the Republic of Indonesia designated to carry out economic functions and obtain certain facilities. SEZs are created by arranging regions with geo-financial and geostrategic benefits and the capacity to oblige mechanical exercises, fares, imports, and other monetary exercises with high monetary worth and worldwide seriousness. SEZ comprises one or a few zones: send-out handling, coordination, industry, innovation advancement, the travel industry, energy, and different economies. In Indonesia, the Specific Economic Zone is a limited geographic area regulated by specific rules and laws [14]. SEZ is also a topographical region where the financial law is not quite the same as the monetary law [15]. It is applied in that country with the main objective being to attract Foreign Direct Investment (FDI). In addition, SEZ can be separated into six sorts: the Free Trade Zone, Export Processing Zone,
Enterprise Zone, Single Factories, Free Port, and Specialized Zone [16].

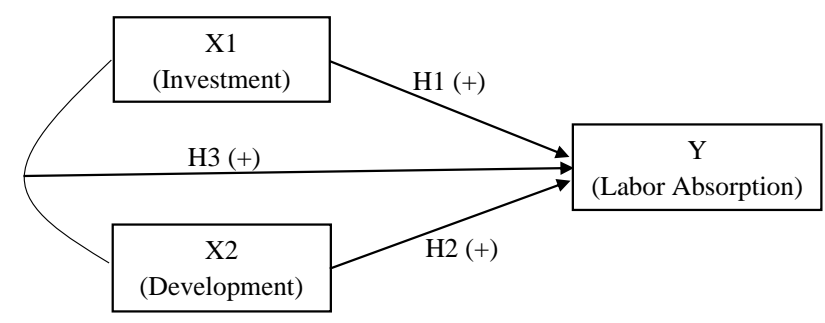

Figure 4. Research Model

\section{RESEARCH METHOD}

Research objects in this study were all Special Economic Zones in Indonesia with a total of 15 areas, including Tangjung Kelayang, Tanjung Api-Api, Mandalika, Sei Mangkei, Arun Lhokseumawe, Likupang, Palu, Bitung, Morotai, Sorong, Kendal, Singhasari, Tanjung Maloy. Batuta Trans Kalimantan, and Galang Batang. Meanwhile, the research subjects focused on SEZ investment, SEZ development, and social impact (labor). This research method used a survey with secondary data (via the web, documents, and data from the Central Bureau of Statistics). From this study's population covering all Special Economic Zones with a total of 15 regions spread across Indonesia, the sampling technique employed non-probability sampling with saturated sampling. Saturated sampling is a sampling technique when all members of the population are used as samples. In this study, the sampling used 15 areas with 43 business units.

The analytical tool in this study utilized simple linear regression. The simple linear regression is as follows:

Simple Linear Regression Model. If there are data pairs $(\mathrm{x} 1, \mathrm{y} 1),(\mathrm{x} 2, \mathrm{y} 2), \ldots,(\mathrm{xn}, \mathrm{yn})$, then the functional relationship of the data pairs are described in a simple linear regression model as follows:

$y=\beta 0+\beta 1 x+\varepsilon$

where the parameters $\beta 0$ (intercept) and $\beta 1$ (slope) are unknown, while $\varepsilon$ is the random error following a normal distribution, with

$\mathrm{E}(\varepsilon)=0$ and $\operatorname{Var}(\varepsilon)=\sigma 2$.

The parameters $\beta 0$ and $\beta 1$ can be estimated with $b 0$ and b1 so that the regression line estimation becomes:

$\mathrm{yi}=\mathrm{b} 0+\mathrm{b} 1 \mathrm{x} 1$

in which b0 and b1 can be calculated from the sample data with the following formula:

$b_{i}=\frac{n \sum_{i=1}^{n} x_{i} y_{i}-\left(\sum_{i=1}^{n} x_{i}\right)\left(\sum_{i=1}^{n} y_{i}\right)}{n \sum_{i=1}^{n} x_{i}^{2}-\left(\sum_{i-1}^{n} x_{i}\right)^{2}}$

$b_{0=} \mathrm{y}-b_{i} \mathrm{x}$ 


\section{DISCUSSION}

\subsection{Overview of Research Objects}

Accelerating equitable distribution of economic development is one of the goals of the Indonesian government. To make this happen, one of the breakthroughs made by the government is through the development of Special Economic Zones (SEZ) in various parts of Indonesia. These areas are determined by the central government based on proposals from business entities and regional governments. On the other hand, Indonesia is the biggest country in Southeast Asia, with a monetary development of $5.02 \%$ in 2019 , in which in 2020 , it contracted to $-2.07 \%$ because of the pandemic; it is projected that in 2021, it will reinforce again to the $5 \%$ financial development rate. Furthermore, Indonesia has the title of "venture grade" by Fitch Ratings. Indonesia also has a consistent development in medium innovation sends out, which mirrors the solid exhibition of the palm oil industry, elastic tires (low and medium innovation), the auto gathering industry, automobile parts, and organization links (high and medium). In addition, Indonesia has the 4th largest population globally with the largest population at a productive age, making it a country with competitive human resources. Indonesia also has abundant renewable (agricultural products) and nonrenewable (mining and mineral) resources. Moreover, Indonesia is the biggest archipelagic country on the planet, which has direct associations with the world's biggest market, with the Strait of Malacca as the world's most dynamic ocean course and the fundamental route for worldwide transportation.

Further, to accelerate achieving national economic development, it is crucial to build a venture through regions' arrangements with monetary and geostrategic benefits. The region aims to amplify modern exercises, fares, imports, and other financial activities with high monetary worth. In its development, to be able to maintain the management of SEZ development in line with world economic and technological dynamics, the government has transformed SEZ development policies by emphasizing orientation towards the realization of SEZs that do not only underline accelerated regional economic growth and equitable development of nationwide (Generation 1 SEZ) but also encourage the realization of SEZs that can build added value for mastery of technology and human resources (KEK Generation 2), which is realized by developing SEZ Health, SEZ Education, SEZ Digital Economy, and SEZ Maintenance Repair and Overhaul. The improvement of the Special Economic Zones is pointed toward making an ideal commitment to accomplishing the 4 (four) public need plans contained in Nawacita, specifically a) creating Indonesia from the outskirts by reinforcing districts and towns inside the structure of a unitary state, b) improving the personal satisfaction of Indonesian individuals, c) expanding individuals' efficiency and intensity in global business sectors, and d) acknowledging financial autonomy by moving the essential areas of the domestic economy. In addition, the objectives for the development of Special Economic Zones are a) increasing venture through the readiness of regions with geo-financial and geostrategic benefits, b) optimizing mechanical, fare, import, and other monetary exercises that have high financial worth, c) accelerating territorial advancement through the improvement of new financial development places for adjusted advancement among districts, and d) realizing an advancement model for provincial improvement for financial development, including industry, the travel industry, and exchange to make occupations.

\subsection{Research Results}

\subsubsection{Testing the Hypothesis of Investment on Labor Absorption}

The results of the discussion revealed that the Indonesian Special Economic Zone business actors include 1) Unilever, 2) Pertamina, 3) JABABEKA-Beyond Property, 4) itdcCreating Destinations, 5) SHMZ, 6) Pupuk Iskandar MudaAceh Indonesia, 7) BWJ, 8) Pelindo 1, 9) Semen Indonesia, 10) Pullman-Hotels and Resort, 11) Mangolian Culture, 12) Sheraton, 13) Sofitel-Luxury Hotels, 14) X2-Resorts, 15) Club Med, 16) Sustainable Vegetable Industry, 17) Kendal Industrial Park, 18) Singhasari Special Economic Zone, 19) Pulisan Bay-Likupang Special Economic Zone, 20) Belitung Maritime Ecotourism Development, 21) MOW, 22) PT. Bangun Palu, Central Sulawesi, 23) BELPI, 24) Pancacita, 25) LAWCO-Indonesian American Water Company, 16) PT. Setra Gita Nusantara, 27) Aice-Have An Aice Day, and 28) API-Alternative Protein Indonesia, with eight other companies not identified.

The data processing results related to the effect of investment on the social impact of labor are as follows. The results of the first simple linear regression test:

Table 1. Model Summary of Investment Variable

\begin{tabular}{|l|l|l|l|l|}
\hline Model & $R$ & $\begin{array}{l}R \\
\text { Square }\end{array}$ & $\begin{array}{l}\text { Adjusted R } \\
\text { Square }\end{array}$ & $\begin{array}{l}\text { Std. Error of the } \\
\text { Estimate }\end{array}$ \\
\hline 1 & $.503^{a}$ & .253 & .195 & 36056.68115 \\
\hline
\end{tabular}

a. Predictors: (Constant), Investment (X1)

In Table 1, the investment variable (X1) had a value of $\mathrm{R}$ square (R2) of 0.253 . It means that the investment variable (X1) could partially explain the variation of changes in the labor absorption variable (Y) by $25.3 \%$, while other variables explained the remaining $74.7 \%$. 
Table 2. ANOVA ${ }^{\mathrm{a}}$ of Investment Variable

\begin{tabular}{|l|l|l|l|l|l|}
\hline Model & $\begin{array}{l}\text { Sum of } \\
\text { Squares }\end{array}$ & $\begin{array}{l}\text { d } \\
\text { f }\end{array}$ & Mean Square & F & Sig \\
\hline $\begin{array}{l}\text { Regressi } \\
\text { on }\end{array}$ & 5716301297.56 & 1 & 5716301297.5 & 4.39 & .056 \\
8 & & 68 & 7 & $b$ \\
1 Residual & $\begin{array}{r}16901095323.3 \\
65\end{array}$ & 1 & 1300084255.6 & & \\
& 32617396620.9 & 1 & & & \\
Total & 33 & 4 & & & \\
\hline
\end{tabular}

a. Dependent Variable: Labor Absorption (Y)

b. Predictors: (Constant), Investment (X1)

Table 3. Coefficients ${ }^{\mathrm{a}}$ of Investment Variable

\begin{tabular}{|c|c|c|c|c|c|}
\hline \multirow[t]{2}{*}{ Model } & \multicolumn{2}{|c|}{$\begin{array}{l}\text { Unstandardized } \\
\text { Coefficients }\end{array}$} & \multirow{2}{*}{$\begin{array}{l}\text { Standardize } \\
\text { d } \\
\text { Coefficients } \\
\text { Beta }\end{array}$} & \multirow[t]{2}{*}{ t } & \multirow[t]{2}{*}{ Sig. } \\
\hline & B & $\begin{array}{l}\text { Std. } \\
\text { Error }\end{array}$ & & & \\
\hline \multirow{4}{*}{$\begin{array}{l}\text { (Constant } \\
1 \text { ) } \\
\text { Investme } \\
\text { nt (X1) }\end{array}$} & 19382.2 & 15852.48 & & 1.22 & .24 \\
\hline & 31 & 5 & & 3 & 3 \\
\hline & & & & 2.09 & .05 \\
\hline & 505.211 & 240.936 & .503 & & 6 \\
\hline
\end{tabular}

From Tables 2 and 3, the investment variable (X1) had a positive regression coefficient of 505.211 with a significance of 0.056, greater than the significant level (alpha) of 0.05 . It shows that the investment variable partially had a positive and insignificant effect on the labor absorption variable. It means that the higher or, the greater the investment, the higher the labor absorption, but the increase in the labor absorption due to the greater investment is insignificant. The factors affecting this investment in the short term consist of the rupiah exchange rate against the United States dollar, the value of exports, the Gross Domestic Product (GDP), and the consumer price index. Meanwhile, for the long term, the influencing factors are domestic interest rates, Gross Domestic Product (GDP), and the consumer price index.

\subsubsection{Testing the Hypotheses of the Development on Labor Absorption}

SEZ development is to create economic growth, encourage participatory development, and increase the nation's competitiveness. SEZs are developed by preparing areas with geo-economic and geostrategic advantages and functions to accommodate industrial activities, exports, imports, and other economic activities with high economic value and international competitiveness. The data processing results can be seen as follows. The results of the second simple linear regression test:

Table 4. Model Summary of Development Variable

\begin{tabular}{|l|l|r|l|l|}
\hline Model & $R$ & R Square & $\begin{array}{l}\text { Adjusted R } \\
\text { Square }\end{array}$ & $\begin{array}{l}\text { Std. Error of } \\
\text { the Estimate }\end{array}$ \\
\hline 1 & $.416^{\mathrm{a}}$ & .173 & .109 & 37929.79118 \\
\hline
\end{tabular}

a. Predictors: (Constant), Development (X2)

Based on Table 4, the development variable (X2) had an $\mathrm{R}$ square (R2) value of 0.173 . It signifies that the development variable (X2) could partially explain the variation of changes in the labor absorption variable (Y) by $17.3 \%$, while the remaining $82.7 \%$ were explained by other variables.

Table 5. ANOVA ${ }^{\mathrm{a}}$ of Development Variable

\begin{tabular}{|l|l|l|l|l|l|}
\hline Model & $\begin{array}{l}\text { Sum of } \\
\text { Squares }\end{array}$ & $\begin{array}{l}\text { d } \\
f\end{array}$ & Mean Square & F & Sig. \\
\hline Regressi & $\begin{array}{r}5716301297.56 \\
\text { on }\end{array}$ & 1 & 5716301297.5 & 4.39 & .056 \\
8 & 68 & 7 & $b$ \\
1 Residual & 16901095323.3 & 1 & 1300084255.6 & & \\
65 & 3 & 43 & & \\
Total & 22617396620.9 & 1 & & & \\
33 & 4 & & & \\
\hline
\end{tabular}

a. Dependent Variable: Labor Absorption (Y)

b. Predictors: (Constant), Development (X2)

Table 6. Coefficients ${ }^{\mathrm{a}}$ of Development Variable

\begin{tabular}{|c|c|c|c|c|c|}
\hline \multirow[t]{2}{*}{ Model } & \multicolumn{2}{|c|}{$\begin{array}{l}\text { Unstandardized } \\
\text { Coefficients }\end{array}$} & \multirow{2}{*}{$\begin{array}{l}\text { Standardize } \\
\text { d } \\
\text { Coefficients } \\
\text { Beta }\end{array}$} & \multirow[t]{2}{*}{$t$} & \multirow[t]{2}{*}{ Sig. } \\
\hline & B & $\begin{array}{l}\text { Std. } \\
\text { Error }\end{array}$ & & & \\
\hline (Constant & 19382.2 & 15852.48 & & 1.22 & .24 \\
\hline ) & 31 & 5 & & 3 & 3 \\
\hline Investme & & & & 2.09 & .05 \\
\hline nt (X1) & כUכ.८ता & 240.930 & (50) & 7 & 6 \\
\hline
\end{tabular}

a. Dependent Variable: Labor Absorption (Y)

From Tables 5 and 6, the development variable (X2) had a positive regression coefficient of 5557.446 with a significance of 0.123 , greater than the significance level (alpha) of 0.05 . It denotes that the development variable partially had a positive and insignificant effect on the labor absorption variable. It means that the higher or, the faster the development is carried out, the higher the labor absorption, but the increase in the labor absorption due to the faster the development carried out is not meaningful. The factors that influence SEZ development comprise security, social, 
cultural, market information and opportunities, institutions, and incentive facilities.

\subsubsection{Testing the Hypothesis of Investment and Development on Labor Absorption}

There are several assumptions regarding the benefits of foreign investment on national economic growth, as follows [17]:

1. Foreign investment will make new organizations extend advertising or bring the innovative work of new advances around them.

2. Foreign investment will increase the competitiveness of the export industry and stimulate the local economy through the second (financial sector) and third (service sector) markets.

3. Foreign investment will increase income tax, boost local/national income, and strengthen the value of the local currency for import financing.

4. Payment of debt is fundamental to secure the presence of monetary products on the worldwide market and deal with the uprightness of the monetary framework. These two things are pivotal for the coherence of improvement.

5. Most of the world's countries depend on foreign investment to provide capital needs for development since local resources are unavailable or insufficient.

6. Advocates of foreign investment argue that once foreign investment comes in, it will become a foundation stone for more investment to come in, becoming a solid pillar for overall economic development

The data processing results related to the effect of investment and development on labor absorption are as follows. The results of the multiple linear regression test:

Table 7. Model Summary of Investment and Development Variables

\begin{tabular}{|r|r|r|r|l|}
\hline Model & $R$ & R Square & $\begin{array}{l}\text { Adjusted } \\
\text { R Square }\end{array}$ & $\begin{array}{l}\text { Std. Error of the } \\
\text { Estimate }\end{array}$ \\
\hline 1 & $.538^{\mathrm{a}}$ & .289 & .171 & 36605.14781 \\
\hline
\end{tabular}

a. Predictors: (Constant), Development (X2), Investment (X1)

In Table 7, the investment (X1) and development (X2) variables had a value of $\mathrm{R}$ square $(\mathrm{R} 2)=0.289$. It means that the investment (X1) and development (X2) variables could explain the variation of changes in the labor absorption variable $(\mathrm{Y})$ by $28.9 \%$, while other variables explained the remaining $71.1 \%$.
Table 8. ANOVA ${ }^{\mathrm{a}}$ of Investment and Development Variables

\begin{tabular}{|l|l|l|l|r|l|}
\hline Model & $\begin{array}{l}\text { Sum of } \\
\text { Squares }\end{array}$ & df & $\begin{array}{l}\text { Mean } \\
\text { Square }\end{array}$ & F & Sig. \\
\hline Regression & 6538154469.41 & 2 & 3269077234. & 2. & \\
6 & & 708 & $.129^{b}$ \\
Residual & 16079242151.5 & 12 & 0 & \\
17 & & 639936845.9 & & \\
Total & 22617396620. & 14 & & & \\
933 & & & & \\
\hline
\end{tabular}

a. Dependent Variable: Labor Absorption (Y)

b. Predictors: (Constant), Development (X2),

Investment (X1)

Based on Table 8, the investment (X1) and development (X2) variables had a positive F-count of 2.440 with a significance of 0.129 , greater than the significance level (alpha) of 0.05. It illustrates that the investment (X1) and development (X2) variables simultaneously or together had a positive and insignificant effect on the labor absorption variable. It means that the greater the investment and the faster the development is carried out, the higher the labor absorption, but the increase in the labor absorption due to the greater investment and the faster the development is not meaningful. The factors affecting investment and development on labor absorption are as follows: the rupiah exchange rate against the United States dollar, export value, Gross Domestic Product (GDP), consumer price index, security, social, culture, information, market opportunities, and institutional and incentive facilities.

Table 9. Coefficients ${ }^{\mathrm{a}}$ Investment and Development Variables

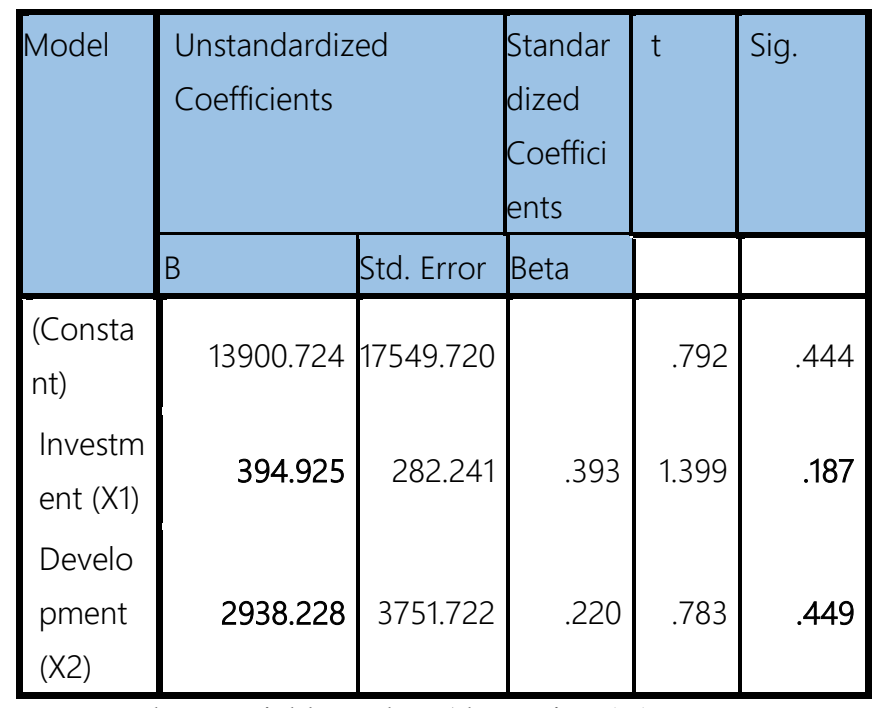

a. Dependent Variable: Labor Absorption (Y)

From Table 9, the investment variable (X1) had a positive regression coefficient of 394.925 with a significance of 0.187 , greater than the significant level (alpha) of 0.05. It signifies 
that the investment variable partially had a positive and insignificant effect on the labor absorption variable. It means that the higher or greater the investment, the higher the labor absorption, but the increase in the labor absorption due to the greater the investment is insignificant. In addition, the development variable (X2) had a positive regression coefficient of 2938.228 with a significance of 0.449 , greater than the significant level (alpha) of 0.05 . It uncovered that the development variable partially had a positive and insignificant effect on the labor absorption variable. It means that the higher or, the faster the development is carried out, the higher the labor absorption, but the increase in the labor absorption due to the faster the development is not meaningful.

\section{CONCLUSION}

From the results of the discussion above, the researchers can conclude as follows:

1. The investment did not have a significant effect on labor absorption.

2. Development did not have a significant effect on labor absorption.

3. Investment and development simultaneously or together did not have a significant effect on labor absorption.

\section{ACKNOWLEDGMENTS}

The authors sincerely acknowledge the financial support of the Directorate of Research and Community Service (DRPM DIKTI) and Research, Publication and Community Service Institutions (LP3M), Universitas Muhammadiyah Yogyakarta in the fiscal year of 2021.

\section{REFERENCES}

[1] Warr, Peter and Jayant Menon, Cambodia's Special Economic Zones, Journal of Southeast Asian Economies 33(3), 2016, pp: 273-290.

https://www.jstor.org/stable/pdf/44132407.pdf?refreqid=excel sior\%3A1a592f31f1d7b790183e69d0ed385897

[2] Zeng, Douglas Zhihua, Special Economic Zones: Lessons from the Global Experience, PEDL Synthesis Paper Series $\uparrow$ No. 1, 2016,

https://pedl.cepr.org/sites/default/files/PEDL_Synthesis_Pape r_Piece_No_1_0.pdf

[3] Moberg, Lotta, The Political Economy of Special Economic Zones, Forthcoming in The Journal of Institutional Economics, 2016,

http://ebot.gmu.edu/bitstream/handle/1920/9639/Moberg_gm u_0883E_10787.pdf? sequence=1\&isAllowed $=y$.

[4] Agustiyanti, World Investment to RI only 1.97 Percent. CNN $\begin{array}{llll}\text { Indonesia } & 31 & \text { August } & \end{array}$ https://www.cnnindonesia.com/ekonomi/2017083111341992-238593/investasi-dunia-ke-ri-hanya-197-persen
[5] Capital Market Authory, Investment. Al-Faisaliah Tower, King Fahad Road Riyadh, Kingdom of Saudi Arabia, 2021, https://cma.org.sa/en/Awareness/Publications/booklets/Bookl et_1.pdf

[6] Laopodis, Nikiforos T, Understanding Investments Theories and Strategies, Second Edition. Routledge 2 Park Square, Milton Park, Abingdon, Oxon OX14 4RN, 2021.

[7] Levišauskaite, Kristina, Investment Analysis and Portfolio Management, Vytautas Magnus University Kaunas, Lithuania, 2021. https://www.bcci.bg/projects/latvia/pdf/8_IAPM_final.pdf

[8] International Monetary Fund [IMF], Balance of Payments and International Investment Position Manual. 6th ed., IMF, 2008.

[9] Mahmoud, F, African Women and Feminists Schools of Thought, In Suliman, M. (ed.), 1991.

[10] Dudley Seers (1972) What are we trying to Measure?, The Journal of Development Studies, 8:3, 21-36, DOI: $10.1080 / 00220387208421410$

[11] UNDP, Human Development Report 1990: Concept and Measurement of Human Development. New York: Oxford University Press, 1990.

[12] Todaro, MP \& Smith, SC, Economic Development. 9th edition. Harlow: PEARSON Add is on Wesley, 2006.

[13] Effendi, Ridwan. Analisis Penyerapan Tenaga Kerja pada Sembilan Sektor Ekonomi Di Sumatera Selatan. Akuntabilitas: Jurnal Penelitian Dan Pengembangan Akuntansi 8(1), 2014, pp 25-52. https://media.neliti.com/media/publications/286761analisis-penyerapan-tenaga-kerja-pada-se-4531e48c.pdf

[14] Walsh, John, Social Policy and Special Economic Zones in the Greater Mekong Subregion. International Journal of Social Quality 3(1), 2013, 44-56.

[15] Khan Nazia and P. K. Varshney, Future Prospects of Special Economic Zones in India in Industrial Sector. International Journal of Marketing, Financial Services \& Management Research 1(12), 2012, 140-15.

[16] A.Bernsein, Special Economic Zones: Lessons for South Africa from international evidence and local experience. Edited proceedings of a Round Table convened by the Centre for Development and Enterprise, The Centre for Development and Enterprise, Johannesburg, 2012.

[17] Kurniawan, Chandra. (2016). Pengaruh Investasi Terhadap Perekonomian Internasional. Jurnal Media Wahana Ekonomika, 12(4), 2016, pp. 1 -9. 